\title{
Statues, symbols and signages: Monuments towards socio-political divisions, dominance and patriotism?
}

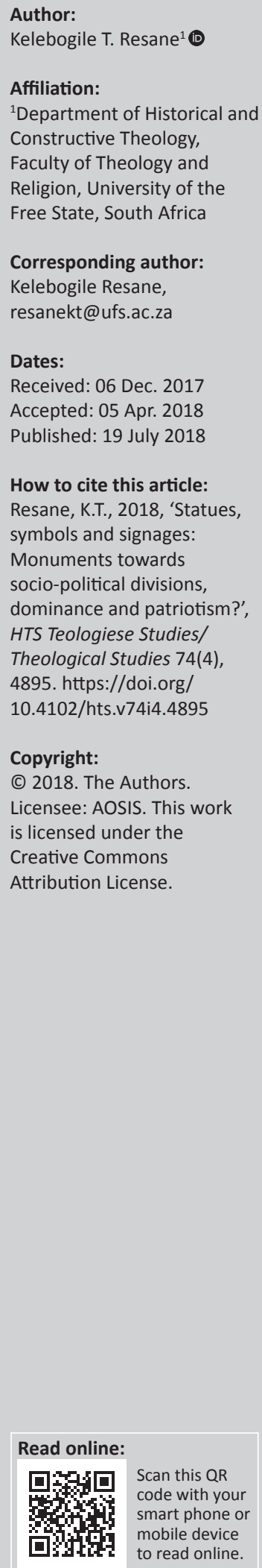

The focus of this article is on monuments variously referred to as statues, symbols, signages, busts, icons etc. The words are used interchangeably. Three words are highlighted to represent a common concept. These are statues, symbols and signages. The South African history with its painful experience of the indigenous inhabitants is highlighted and how symbols had to change in 1994 to represent the aspirations of the new democratic dispensation. Biblical reflections on monuments demonstrate the importance of these symbols during the Old and the New Testament times. The two symbols singled out to reinforce this notion are the Holy Communion and the cross. The significance and potency of the monuments is explained and conclusion drawn is that symbols are valuable for didactive purpose because they serve as teaching aids. They also serve the memory for generations to come so that they know how God's faithfulness has been demonstrated in the national history of Israel, therefore serving missiological function of the church today.

\section{Introduction}

From time immemorial, apart from oracles, people asserted their origin, meaning, ethnicity, piety, religion and power through images. 'The city squares of the Greek era were crammed with statuary of gods and elites' (Nasrallah 2011:171). From the coin in the pocket to the sculptures that gazed down on walking people around the city and the cultic centres, or the agora, emperors and elites made statements about their piety, cultural knowledge and prowess. The literature on iconography points to statues, symbols or monuments focusing on feminine sexuality and male artificial deity (Hersey 2009; Nasrallah 2011). Nakedness, pleasure, virility, dexterity, divinity and ethnicity seem to have taken centre stage crafted in statues, symbols, icons, monuments and sculptures. Iconography leans more towards religious symbols than secular symbols such as statues, busts, monuments etc. Religion is extensively coloured with monumentalisation:

Monuments more than often have a spiritual character and iconic value, in the sense that they offer a space for the formation or discovery of meaning. (Cilliers 2015:2)

Monuments such as statues play an important symbolic role in people's lives, with each monument being built for specific reasons and intended to serve particular purposes or interests. Monuments are erected as part of a visual culture that continually reminds us of something or someone important; yet, the symbolic value of monuments may change. Such values may acquire or lose importance, depending on fluctuating socio-political dispensations and dispositions.

In this article, various words are used interchangeably as they convey the same meaning and outcome. Words used include statues, symbols, signs, icons, monuments, busts, memorials or memorabilia, emblems and in some places, sepulchres.

\section{The monuments}

\section{The statues}

A statue is a sculpture representing a person or persons, an animal or an event, normally full length, as opposed to a bust. A statue comes at a huge price as is made of materials like clay, marble, resin, bronze, porcelain, fibre glass etc. The latest contentions for statues, especially of the former President of South Africa, are always attached more to the cost than any significance. For instance, in the North-West Province, the opposition parties argued that President Zuma's statue is costly and funds could be directed elsewhere for poverty alleviation in the province. Not only is a price attached to statues but also the aesthetics and admiration, as Bobou (2015) asserts:

But statues were more than objects of admiration. Their cost, quantity, and placement, as well as the types used for the representation of gods and mortals show that their role was far more important than that of a decorative object that could be admired for its technique, style, or subject. (p. 4) 
This theme on statues had become prevalent in South Africa since 09 March 2015 when the students of University of Cape Town cried and appealed for the fall of the statue of Cecil John Rhodes which occupied the intersectional space of institutional public entrance. The statue of Rhodes was targeted as the man was a megalomaniac British colonialist. His legacy will always be attached to the Glen Grey Act - a policy that became a blueprint for the consequent apartheid legislations restricting black people to the access and ownership of the land. This culminated into the formalised migrant labour system that broke the family and communal ethos of the indigenous people. In the words of Headley and Kobe (2017), the man built:

a history characterised by land conquest, the quest for cheap labour, political oppression, white supremacy, discrimination and domination which were often legitimised in the name of Christianity. (p. 2)

The statues and the busts of Rhodes suffered sporadic setbacks, nationwide, after the dawn of democracy. A memorable example was in Mahikeng:

When a part of the old town station was demolished in the mid1990s to make way for a shopping mall, the statue was moved to an inauspicious location at the Mahikeng Transnet train yard. It was this relative obscurity that signaled its last days in Mahikeng, the northern town that was a key stop in Rhodes's ambitious Cape-to-Cairo rail project. ${ }^{1}$

Cecil John Rhodes' statues were vandalised and defaced as they represented the ensuing colonial dominance and power, while those of Hedrick Francois Verwoerd suffered the same as they represented apartheid history and its anomalies.

It looks like Verwoerd's statues and busts were the most targeted throughout South Africa, for obvious reasons, as the man who within 8 years as a Minister of Native Affairs:

rapidly made South Africa, and the world, recognise him as 'the Architect of Apartheid', thoroughly earning the title which, in justifying it, brought him to political eclipse. (Allighan 1961:xi)

Following the emergence of democracy in South Africa, the Free State Province slumped into media turmoil by removing the statue of H.F. Verwoerd. One newspaper reported:

Just as the Berlin wall and statues of Lenin came down in recent years, the statue of Hendrik Verwoerd, the Prime Minister who drew the map of segregation and imposed inferior education on blacks, was wrested from his place in front of the provincial offices of the Orange Free State during a Friday afternoon rush hour. ${ }^{2}$

In 2011, just before the local government elections, the Democratic Alliance - the main opposition party in South African politics 'removed a statue of the architect of apartheid, Hendrik Verwoerd, in Midvaal, south of Gauteng'. ${ }^{3}$ In 2015,

1.https://mg.co.za/article/2014-06-26-the-peculiar-search-for-the-statue-of-cecilgone-rhodes

2.http://www.nytimes.com/1994/09/25/world/apartheid-is-demolished-must-itsmonuments-be.html (viewed 17 August 2017).

3.http://www.sowetanlive.co.za/news/2011/05/05/verwoerd-statue-is-gone (viewed 22 August 2017). the students of Stellenbosch University joined in echoing the removal of the plaque commemorating the apartheid leader, an act that was endorsed by Verwoerd's grandson who said his grandfather:

and other apartheid leaders should no longer be honoured in public spaces... since, honouring his grandfather rubbed salt in the wounds of black South Africans. ${ }^{4}$

The majority of South Africans continue to refuse 'Hendrik Verwoerd as a "figure of memory" that can be emulated, more importantly, as an image that can inspire collective identity' (Dube 2015:2). Apart from Rhodes and Verwoerd, another development was in the North-West Province. The statue of Chief Lucas Mangope of the erstwhile Bophuthatswana was removed from the Lehurutshe Civic Centre, near Zeerust, contrary to the district's residents. A North-West communication service press statement on 21 September 1995, on the removal of former Bophuthatswana president Lucas Mangope's statue from the Lehurutshe Civic Centre, quotes then North-West chief whip Joe Selau as saying that: 'the mandate of the people has been carried out'. This was despite Lehurutshe residents complaining that they weren't consulted by the government about the removal. ${ }^{5}$

The North-West Provincial took this decisive step as a pragmatic action of deleting Bophuthatswana from the memory of the citizenry in that geographical part of the country. The action is expected to spread all over the country as a means of pioneering the new patriotic spirit of the new democratic dispensation. One reads, hears and sees of the sporadic actions against or for statues through South Africa.

The University of Cape Town students' action morphed into a spiral wave of protests, culminating into unprecedented debates regarding statues and busts around the country. Consequently, statue removals at the Union Building in Pretoria and in front of the parliament in Cape Town and some other cities and towns around the country instigated some robust discussions. This sends a clear message for transparent national discourse:

The wave to dismantle all statues attached to the history of colonialism, apartheid and white supremacy; it is not just a battle for public space but one of identity and belonging. (Mashau \& Mangoedi 2015:1)

Statues had become a bone of contention. This is because of the historical marginalisation of the indigenous leaders and heroes who played some inexpressible roles in liberation struggles and the development of the particular geographic inhabitants. In the heritage archives and memorabilia, the efforts of these heroes were ignored, unrecorded or unrecognised. For instance, when the

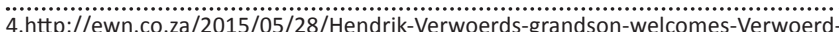
plaque-removal (viewed 22 August 2017).

5.https://mg.co.za/article/2014-06-26-the-peculiar-search-for-the-statue-of-cecilgone-rhodes (viewed 22 August 2017) 
Batswana chiefs tried to abort the Boers invasion of their land:

Montshiwa responded by appealing for British intercession while simultaneously trying to enlist the support of Batswana allies sympathetic to his cause. He approached the Bahurutshe under Ikalafeng in the Marico district, who sent a regiment under his uncle to assist the Tshidi Barolong. As the Hurutshe were resident in the Transvaal, this did not sit well with the Boer authorities. Anticipating an attack, Ikalafeng placed stone fortifications around his capital at Dinokana. In February 1882 a commando was sent against the Bahurutshe, and Dinokana was captured without a shot being fired. The stone fortifications were pulled down and piled up as a so-called 'monument to peace'. A monument honouring Chief Montshiwa exists in Mafikeng and should be included in the national liberation heritage route. ${ }^{6}$

Very few people, if any, would know anything about Chief Montshioa's monument, or the sefikantswe that is found in Dinokana today. There are hundreds of these landmarks throughout the country, but were never given a rightful position of recognition. Instead the colonial and apartheid figures are prominently situated in cities, platteland dorpies, institutions and heritage sites across the land. The reaction can be justified, rightly or wrongly, because the nation is still divided and attached to imbalances of the past. As Headley and Kobe (2017) point out:

Current challenges around social cohesion amidst harsh inequalities in South Africa are shaped by the legacy of imperialism, colonialism and apartheid. (p. 2)

Colonial disruption and imposition of foreign cultures upon the social fabric of African life wrecked the conceptual frameworks of the indigenous inhabitants of Africa. This was brutality legalised under the apartheid. Wilkinson (in Coetzee \& Roux 2000) captures this anomaly:

Apartheid was a shameful and deliberate attempt to alienate Africans from all forms of cultural stimulation which, as a result and as planned, undermined self-confidence and will. (p. 389)

The deliberate intentions of ignoring, side-lining or marginalising the artistic expression of cultural heritages (monuments, statues, symbols etc.) robbed people of tracing their historical heritage. The perpetrator's intention is that the subjects or victims' humanness (ubuntu) be painted off their memories in order to coerce or to oppress them. If people do not know their history, they become the victims of greed and selfishness that is initiated by others. This act comes as a military imagery to defend or destroy the minds of the victims just as 'the army's constructive impact and of its potentially destructive role on local communities and their economies' (Punt 2016:215). It is the act ad summum [to the highest point] of social destruction and exclusion, racism that 'seeks to eliminate another on the basis of differences that it believes to be hereditary and unalterable' (Fredrickson 2002:170). Subsequent to indirect colonial rule that left Africans disempowered, apartheid proponents enhanced ideological odium humani generis [hating the human race] that promoted misunderstanding and intertribal hatred. This ideology heightened the negative image of Christianity, by encouraging the abandonment of indigenous knowledge systems, therefore stamping out the indigenous Christian people as outsiders to a broader society. The defaulters were regarded as potentially dangerous, in some cases facing possible punishment by missionaries or indigenous authorities. Villa-Vicencio and Grassow (2009:108-111) cite a typical example of how Chief Montshioa of Barolong-bo-Ratshidi clashed sharply with his brother Molema, who was a strong Wesleyan preacher. The bone of contention was that Molema's gospel message convinced the tribe to abandon cultural practices, especially bogwera [initiation practices].

\section{The symbols}

National symbols are defined as the symbols or icons of a national community, used to represent that community in a way that unites its people. Ginty (2001) elaborates:

Symbols and symbolism can act as a vehicle for the development of an identity bond between the individual and the group and for group solidarity. They can also help promote a certain worldview and mobilise emotions and people. While symbols and symbolism are evident in mass phenomena such as ethnic mobilisation and nationalism they often play more subtle and calming roles in society. (p. 2)

The common national symbols include the coat of arms, flag, anthem, an item such as a bird, animal, tree, flower, etc. The nation rallies under these symbols to express their cohesion, patriotism or allegiance. They are the symbols of identity and nationality. In the biblical context, they serve as object lessons (VanGemeren 1990:33). Examples here include Passover lamb, 12 stones placed in the middle of the River Jordan when children of Israel crossed into the Promised Land. These were to serve as object lessons for God's deliverance to the coming generations. In the words of Louw (2016):

Symbolisation and aesthetic signification are integral ingredients of Christian reflection on meaningful perspectives for life and significant religious experiences of divine presence. (p. 4)

National symbols have the potential to unite or to divide. This is as a result of their ambiguity as they 'suggest meaning rather than stating it' (Mickelsen 1977:265). Prior to 1994, the then South African national symbols were objects of national division, as the nation was segmented into racial, tribal or ethnic cloves and cohorts. These symbols were identity signs for one particular racial group. South Africans, especially black people, were always hurt at the international events when the then South African national flag had to be hoisted. Nationally, it was never a symbol of patriotism or pride, including some religious spaces where it was never hoisted, since:

the regime's injustices had put it beyond the pale of civilised nations and its orange, white and blue flag had become a pariah symbol of racism and oppression. (Storey in Bentley \& Forster 2012:1) 
The old South African anthem was also regarded by the majority population as something not melodic or diatonic. It was a foreign song to the majority of the citizens, regarded as a symbol of empowering the oppressor or promoting the ideology that victimised others. This is captured by De Gruchy (2008) stating that:

National emblems, such as flags for example, have iconic significance for many, binding people together in common purpose. But they can become idolatrous when a nation embarks on policies that are oppressive and destructive - especially when pursued, as often as they are, in the name of God. (p. 20)

South African history is painful and hurtful to the majority of the citizens, especially the indigenous inhabitants. These people see the monuments that bear no aesthetics or romance for them. These people cannot connect their history or culture to these symbols. The symbols evoke the memory of the painful past. Dube (2015) rightly asserts:

The busts represent a particular historical period and persons, and therefore emit 'mnemonic energy'. As figures of memory, they demand us to ask why these particular individuals. (p. 2)

In 1994, the new symbols had to be adopted or adapted to expedite national unity and generate a new form of patriotism and democratic national unity. Ginty (2001) reminds us:

A programme of national unity (Masakhane or building the nation together), was created and made heavy use of symbols and symbolism in the promotion of a new brand of civic nationalism. (p. 12)

The then ethnocentric politics had to be de-centred through the implementation of the new symbols. These symbols had to be authentic and deeply symbolic to foster togetherness that can reconcile relationships and heal the brokenness (De Gruchy 2008:20ff). These new symbols had to promote justice, peace, wholeness and national authenticity. They were not designed to promote greed, corruption, violence, war, sexual exploitation, denigration of the body or history that is shameful and dehumanising. The primary function of the symbols is 'to make explicit the images by which a society recognises its own values' (Onyewuenyi in Coetzee \& Roux 2000:396). Symbols have the potency of transporting the memory to the lofty realm of enlivening the metaphysical to corporeal senses. Symbols express an 'abstract or transcendent concept, connecting two different realms' (Ito 2015:77). Even in African Christianity, spectacularly with African Indigenous Churches, symbols and symbolism play a significant spiritual identification. 'Symbols are meant to enrich spiritual experience and to point beyond the visible to the invisible' (Pretorius \& Jafta in Elphick \& Davenport 1997:223).

\section{The signages}

These are the signs or a system of signs used to show information about something in history such as a building or a road. In South Africa many buildings, institutions, roads or streets acquired the new names consonant with liberation struggle and heroes. Signs had to be mounted to these landmarks to demonstrate the new era of democracy.
Signages are not just for identification but also for warning and giving direction. Signs are critical in religious expression. Cilliers (2015:2) cites Peter Berger (1994:144ff.) who has argued extensively that religion represents, among other things, the longing for meaning and that one of the ways in which this longing is fulfilled is through the creation of structures that act as signs of, and for, transcendence. These signs or signals of transcendence should, however, never be seen as evidence of the transcendence - an interpretation of this nature always remains a discernment through faith.

In a collective form, statues, symbols and signages all serve as the monuments that convey the message of either national history or collectivism. A monument is a statue, building or other structure erected to commemorate a notable person or event. It may be a structure placed over a grave in memory of the dead, or a historical site of importance or interest: A monument is an enduring and memorable example of something. It is for this reason that these icons command some indelible power to resuscitate memories. Beholding them revives the history. Berenson $(1902: 121,124)$ claims that it is within the human nature that when a great artwork is seen, there is a feeling of poignant thrill of transfiguring sensation. In another place, Berenson (1930) reinforces this fact that 'When the viewer looks at a tactile work, his or her life gets and extra surge of force'. The South African society is still significantly divided along the racial lines, the rich and the poor, the economically marginalised and the benefactors, the beneficiaries and the victims of apartheid etc. The statues, symbols and signs bring history closer to the present. For the elite members of the society, however, these symbols are deniably important:

from its gods and goddesses to its heroes and benefactors, from commemorations of the dead in battle to commemoration of miracles affecting single families. Marks of wealth and social power, they were also signifiers of piety and honour, placed in sanctuaries and public settings like the agora, the theatre, or the gymnasium where one's honour was most displayed, acknowledged, and admired. (Bobou 2015:4)

However, as De Gruchy (2008:20) alludes: 'Not all images are worthy of adoration or emulation, and some represent values that are dehumanising, degrading and destructive'. The current generation looks at them as aigre doux [sourness or bitterness] that opens the wounds of the painful historical events. So, when the historically disadvantaged masses behold these monuments, the memory kicks out of the shell because these symbols in various forms express the painful past, and in recent cases, the imbalanced present. These icons are indeed the instruments of torture to the memory. They open up the wounds instead of healing them, though historically, the icons, especially in the Orthodox traditions, 'are a living memorial to the Divine energy and a means of receiving healing and grace' (Nicolaides 2014:78). If the symbols or monuments were properly interpreted from the religious perspective, they would make God real and fathomable. Joubert (2017) is correct that:

These visual manifestations of deities served as the basic system of reference in terms of how people came to know and interpret the divine. The memory of such encounters was expressed in 
poems, epic stories, votive reliefs, and so on, but also by means of various symbolic expressions and actualisations of the divine in sanctuaries and rituals. (p. 1)

It'll be ideal to understand definition of icons. It has been stated that icons are monuments or symbols that assist the memory to contemplate on one's historical or cultural origins. Vlachos (2017) helps in understanding the icon from a religious perspective:

In common language, the word 'icon' means 'image'. However, from the time of the early Christian Church, the word 'icon' is generally used to denote images with a strong religious content, significance and use... All icons represent a religious topic and for them to be acceptable should not simply be a representation of a religious subject, but rather, an expression and representation with a religious significance. (p. 1)

If all the icons were of exclusively religious significance, the religious populace would agree that they are a theology in colour, representing the gospel artistically and reflecting images of holy and heroic Christians. Secular history took over iconography to falsify the true expression of divine contemplation. Hence, the statues had become a stench in the nostrils of the socially excluded masses. This is exacerbated by ambiguity that opens the possibility whereby 'the interpreter is forced to be subjective' (Mickelsen 1977:265). Monuments in any format command some iconic power in the mind and the conscience of those who see them.

\section{Biblical reflections on monuments}

The Old Testament text starts to refer to monuments from the era of Noah, who 'built an altar to the LORD and, taking some of all the clean animals and clean birds, he sacrificed burnt offerings on it' (Gn 8:20). From there on, altars became a practice for the patriarchs when in some instances, 'serving merely as a memorial to a theophany or a miracle, and in other instances libations were poured on pillars' (Heger 1999:264-265). Throughout the Bible, an altar indicates approach to God, or communion with him. It was often the place of sacrifice, teaching that humanity can and is expected to always be in communion with him.

The patriarchs in their nomadic lifestyles settled in one particular geographical setting by pitching up a tent, building an altar and digging the wells. The important image was the altar; as it demonstrates that from the ancient times, people were always the worshippers of a deity through some form of sacrifice. Hersey (2009:52) affirms that 'Making the image was part of the individual worshiper's act of sacrifice'. Apart from the altar, the Old Testament presents some narratives on the ark, which was closely associated with the sanctuary, a cultic centre where YAHWEH was to be invoked. The sanctuary, from the early days of wilderness wanderings, 'accompanies the history of the people as a special sign of the divine revelation' (Hertzberg 1974:47). The story of the symbolic incarnation of YAHWEH in the form of an ark is epitomised in the days of Eli as both the priest and the judge in Israel. This was the turbulent times of erratic but constant wars of the Philistines against the Israelites. The two nations possessed differing perceptions about the ark. For Israel, the ark was a symbol of God's accompaniment and presence, while for the Philistines it was an idol on the same position as their god, Dagon. In their view, the ark 'belongs as a cult emblem' (Hertzberg 1974:53). For Israel, the ark was never perceived as 'a supernatural means of guaranteeing victory. Yahweh is not bound to the ark; he shapes history independently of the symbol of his constant presence' (Hertzberg 1974:51). The religio-historical outlook of these two nations was blended and intertwined with symbols or emblems. This does not differ much from the modern ideology regarding monuments. They retell national history and heritage, and they express the ingrained selfhood or national identity. It is for this reason that these monuments are an emotive issues and bones of contention in a national discourse. The Old Testament monuments' locus is captured by Cilliers (2015:9) that the God they worshipped was dynamic in some way:

Indeed, God is a God that moves. God is not a monument, but movement. God, (not) needing time and space, moves through time and space. God moves within the realms of culture, cosmos and the dynamics of human relationships. God is the God of the tabernacle, the tent of transit, not the gravity of granite. (p. 9)

The two symbols of Christianity are used as reference to express the value and the place of symbols in the Christian faith. These are central to the Christian. The first was derived from the Old Testament with symbolic metaphorical reference to the New Testament.

\section{Holy Communion: The symbolic representation of Christ's unity with his people}

One of the memorable symbols central to Christian faith is the Passover Lamb, articulated to the New Testament Holy Communion; designated with different names. The biblical juncture clarifies its purpose: 'In days to come, when your son asks you, "What does this mean?" say to him, "With a mighty hand the Lord brought us out of Egypt, out of the land of slavery"' (Ex 13:14). Its climatic efficacy is the Lord's Supper in the New Testament. It is a sacramentum - a mystêrion referring to the unveiling of the end of history (Van der Kooi \& Van den Brink 2017:599). In this case, the history of the redemptive work of Christ. The Lord's Supper is wrapped up in mysterious symbolism. The central fact is that 'sacraments are liturgical enactments that symbolize a sacred reality' (Husbands \& Treier 2005:212). In summarising Berkhof (1941:650), this sacrament is a symbolical representation of the Lord's death. It symbolises the believer's participation in the crucified Christ. It represents not only the death of Christ as the object of faith and the act of faith which unites the believer to Christ as well as the effect of this act as giving life, strength and joy to the soul. It also symbolises the union of believers with one another - the act of the Holy Spirit, 'who makes Christ present through the faith of the believer in the act of communing' (Peters 2000:302). By virtue of participation, believers enter 'into communion with the living Lord' (Ridderbos 1975:419). It does the same task as 
national monuments: constituting patriotism, linking common historical heritage and forging cohesive identity. In a religious sphere, it is 'an attempt to present the divine communication in an understandable way' (Du Rand 1994:250). Through participation, one acknowledges connectedness to the wider community, the church. It is declaration that one is part of the body and his or her life is interwoven to this body and is connected to the head, Jesus Christ.

\section{The cross: The symbol of Christian identity}

However, the most common symbol of Christianity is the cross. It is the universal symbol that is like a graffiti on the wall noticed by passers-by, though not taken cognisance of. One evangelical scholar, John Stott (2009) elaborates on the cross as a central symbol of Christianity. He laboriously expands the different traditions' emblems that ended up as of sacrosanct identities of these nations (2009:26-32). The cross was viewed as a symbol of a shameful execution of a common criminal. Ward (1999) rightly affirms:

The symbol of the cross suggests that the creation of finite persons involves a definite risk for God, the risk of rejection and suffering. (p. 99)

Through ages, it became a symbol of life accompanied with contradictory binaries. 'The cross was an act simultaneously of punishment and amnesty, severity and grace, justice and mercy' (2009:187). Moltmann (1993:33) alludes to the fact that the Israelite understanding was that someone executed on the cross was rejected by his people, cursed by God's people and of course, excluded from God's covenant. However, for Christians:

The cross of Christ is the symbol of the divine love, participating in the destruction into which it throws him who acts against love: This is the meaning of atonement. (Tillich 1970:115)

The cross is a revolving point whereby Christianity interprets itself. It is the seedbed of Christianity and it serves as a premise for theological discourse. 'No theology is genuinely Christian which does not arise from and focus on the cross' (2009:251). The cross is an emblem with symbolic meaning in African Christianity. In African Indigenous Churches, 'Christian identity is most often symbolized by cloth crosses, worn by members, or wooden crosses carried in processions' (Pretorius \& Jafta in Elphick \& Davenport 1997:223). Amazingly, even the African Traditional Religion practitioners, when making any mark, as a sign of protection, power or promotion, they will use the mark or the sign of the cross. The cross preaches in silence, but potently to the beholder. It occupies the central place in places of worship, therefore singling out that sanctuary or shrine as a Christian holy space of worship. The cross distinguishes Christian faith from the world religions, secular ideologies and utopias. It is for this reason that theologia crucis [theology of the cross] is 'the key signature for all Christian theology' (Moltmann 1993:72). Theological statements that seek to be genuinely Christian are viewed from the perspective of the cross.

\section{The significance of the symbols}

People in history, past and present, always built monuments to memorialise the achievements of either themselves or others such as their heroes. In this context, a symbol was to serve as a reminder of a significant historical event that is not just a narrative but a lesson on the goodness of God. The symbols here were to perpetually make a national history alive. Ginty (2001) impresses this fact:

Symbols also perform a bridging function, linking the past with the present. While not always historically accurate, these symbolic linkages often make some reference to a real past or 'symbolic capital'. (p. 3)

They serve as a reminder to successive generations of historical events and great human accomplishments. For instance, Moses commanded the Israelites to take the two quarts of manna to be kept as a museum specimen forever, so that later generations could see the bread that the Lord provided for the nation in the wilderness. This was to be kept in a sacred place from generation to generation (Ex 16:32334). When the Israelites crossed the River Jordan, some designated tribal leaders were commanded to 'return to the riverbed to secure stones for the memorial which would be a vivid reminder of God's work of deliverance, and an effective medium to teach the young' (Campbell 1981:34). The stones stood 'as a tribute to God's great power' (Getz 1979:74). This was to entrench the national history and identity. It is for this reason that 'the busts across South Africa were not erected, merely, to fill-in empty city spaces, but to spell out identities' (Dube 2015:3).

The monuments in the Bible served as a reminder for the generations to come, the significant and historical event, and a pact of covenant between the two parties. They served as a testimony to the mighty acts of God in the life and movement of the nation. This is impressed by passages such as Joshua 4 and Exodus 13 where they served as object lessons that opened opportunities for parents to teach children of the historical mighty acts of God. Of great interest is that the historical knowledge was not limited to the nation of Israel, but so that all the peoples of the earth might know that the hand of the Lord is powerful... (4:24). God is missional. He is not a national deity, limited to one particular nation. In the words of De Gruchy (2016:39), 'God is not the tribal deity of the warring Israelites, but the creator and redeemer of all peoples and nations'. His character is that of grace and mercy, calling on his people to appropriate rituals and rites as a means of pursuing peace, justice and compassion:

Whether one uses the terms 'emblems', 'sacraments', or 'ordinances' is not the important thing. What is important is how one responds to the meaning that God has given to these sacred rites. These are not mechanical rituals. They are God-given expressions of grace, of what God has done, is doing, and will do in Christ. (Mickelsen 1977:278)

The statues, symbols and signages were the monuments for reviving both national and international historical events. National and international missions as purposed by these 
symbols, showcases God's heart for universal human redemption. They reveal God's justice 'in an ultimate and therefore symbolic sense' (Tillich 1970:111). It is clear that arts and culture play a significant role in forming religious conviction and formation. Monuments are connected to religious motifs. They seldom escape the lure of power. This is expressed vividly by Cilliers (2015) that:

The monumentalisation of religion in fact often represents an act of power in itself. Monuments cannot be understood in isolation from their cultural settings; monumental thinking always correlates with culture and the endeavour to create bases for power in which political aspirations and religious symbols often overlap and even become identical. (pp. 3-4)

The bottom line is that all symbols in any format are the expression of culture, including religion and history. In disintegrated or separated society, they can become a stench to be abhorred at all cost, hence subjected to defacing, removal or destruction whenever there is a political wave that calls for the change in or of status quo.

\section{Conclusion}

In South Africa, symbols had become bones of contention as a result of historico-cultural scaffolding of the past four centuries. They promoted separateness, enhanced colonialism and entrenched apartheid ideology. The new symbols and signages aimed at unification of the nation to promote love, tolerance, harmony and distributive justice for reconciliation and equality. They are open to interpretations because of changing contexts. This calls for round-table discussions of those in political seats of power to foster agreement, if they agree that monuments are to enhance or expedite the process of national reconciliation. Cilliers (2015) highlights the fact:

The current government in fact seems to have adopted a fairly low-key approach to certain former symbols of Apartheid, with new agreements recently being made between the custodians of the Voortrekker Monument and those of Freedom Park, in an effort to foster reconciliation in South Africa. (p. 5)

These monuments should contribute towards didactical values, that is, serving as teaching aids. This should be their primary function, which may be either a formal function whereby its purpose and use is formally prescribed or an auxiliary function when it is used for illustrative purposes (Sinding-Larsen 1984:29). They serve as a memory for the national history and the anticipated future of the nation. It all revolves around the legacy to be passed on to the next generation. Cilliers (2015) is spot on that:

Remembrance as such is part and parcel of being human. Monuments that call upon us to remember are, and will be, with us as long as there is history to remember. Remembrance forms a characteristic part of all religions; religion has always had a memorial aspect. Christianity could also be called a religion of remembrance. (p. 6)

The moment the symbols promote social exclusion, the division becomes inevitable and national unity and cohesion far-fetched. There is either a denial or some utopian ideal that after 1994, all things are smooth and harmonious. The fact is that the new symbols are still suffering in the hands of some supremacists and traditionalists who claim life was better in Egypt (apartheid South Africa) than in the wilderness (democracy without water, electricity, jobs etc.). Some see beds of roses without thorns or bees with capacity to sting. It is ironic, as Senokoane (2015:7) says, that 'The cementing of white symbols has also been hidden in the concepts of equality for all and humanity'. At the end of the day, monuments are supposed to unify the nation rather than dividing it. In a religious sense, to align with De Gruchy (2008), icons are supposed to be the means of grace. Like in the patriarchal era, monuments are the points of divine encounters, holy spaces that revive connection with the divine where theophany is realised. This is confirmed by Rhodes (1998:61) that 'Crosscultural encounters can liberate Christians from their own ethnocentrism'. The dictum remains: 'Do this in remembrance of $\mathrm{me}^{\prime}$. These memorials conscientise humanity of its origins, histories and culture. The American church specialist, Mancini (2008) correctly captures this that:

By connecting dots with the past, we bring new meaning to the present and walk into the future with a stronger sense of identity. (p. 76)

This article advocates the value of monuments as a reminder and as teaching aid. History has always been a good teacher. It explains our present and helps us to chart the way forward. History may be full of negatives to make our present sour, memorially, but:

The past remains an obstinate aspect of the present. We do not live within a vacuum, but within a context, the intellectual, cultural, and social contours of which have been shaped by the past. (McGrath 1997:82)

Symbols are a living history, which is the arena within which the Christologically centred dialogue between God and humanity takes place. They are theatrum gloriae Dei-a theatre of the glory of God, an arena within which the glory of God may be discerned and recognised. 'A flight from history is improper and impossible' (McGrath 1997:92). The call for the removal or destruction of the monuments that do not heal but open up the wounds can to a certain degree be justified. It is a bold appeal to correct the imbalance of the past, to call to correction what was deliberately an injustice. What I am trying to drive here is better explained by Parsely (2007) that:

The culture isn't demanding that we sacrifice a pig on a holy altar. The culture demands something even more profane - that we sacrifice the truth of the gospel on the altar of political and cultural correctness. (p. 213)

The problem is not the monuments, but people who construct them. Their reasons are always the promotion of egoistic ideals that undermine others. Jeremy Gordin (2008:303), in his biography of the current President of South Africa says: 'Don't throw your spear at the flag. Throw it at the man holding the flag, but not at the flag'. The symbols must promote nationhood and patriotism, not division or proliferations into ethnic enclaves. 


\section{Acknowledgements Competing interests}

The author declares that he or she has no financial or personal relationships which may have inappropriately influenced him or her in writing this article.

\section{References}

Allighan, G., 1961, Verwoerd - The end: A look-back from the future, Purnell \& Sons (SA), Cape Town.

Berenson, B., 1902, The central Italian painters of the renaissance, 4th Impression, G.P Putnam's Sons Press, New York.

Berenson, B., 1930, The Italian painters of the renaissance, rev. edn., Clarendon Press, Oxford.

Berger, P.L., 1994, Sehnsucht nach Sinn. Glauben in einer Zeit der Leichtgläubigkeit, Campus-Verlag, Frankfurt.

Berkhof, L., 1941, Systematic theology, The Banner of Truth Trust, London.

Bobou, O., 2015, Children in the hellenistic world: Statues and representation, Oxford University Press, Oxford, UK.

Campbell, D.K., 1981, No time for neutrality, Victor Books, Wheaton, IL.

Cilliers, J., 2015, 'God in granite? Aesthetic-theological perspectives on the monumentalisation of religion', Scriptura 114 (2015:1), 1-13, viewed 17 April 2017, from http://scriptura.journals.ac.za

De Gruchy, J.W., 2016, Without apology: Faith, hope and love in a time of doubt, despair and violence, Methodist Publishing House, Woodstock, GA.

Dube, Z., 2015, 'The statue debate: Ancestors and "mnemonic energy" in Paul and now', HTS Teologiese Studies/Theological Studies 71(3), Art. \#3035, 5 pages. https://doi.org/10.4102/hts.v71i3.3035

Du Rand, J.A., 1994, Johannine perspectives: Introduction to the Johannine writings, Orion Publishers, Pretoria.

Fredrickson, G.M., 2002, Racism: A short history, Princeton University Press, Princeton, NJ.

Getz, G.A., 1979, Joshua: Defeat to victory, Regal Books, Glendale, CA.

Ginty, R.M., 2001, 'The political use of symbols of accord and discord: Northern Ireland and South Africa', Civil Wars 4(1), 1-21. https://doi. org/10.1080/13698240108402461

Gordin, J., 2008, Zuma: A biography, Jonathan Ball Publishers, Johannesburg.

Headley, S. \& Kobe, S.L., 2017, 'Christian activism and the fallists: What about reconciliation?', HTS Teologiese Studies/Theological Studies 73(3), a4722. https:// doi.org/10.4102/hts.v73i3.4722

Heger, P., 1999, The three Biblical Altar Laws: Development in the sacrificial cult in practice and theology, political and economic background, Walter de Gruyter, Berlin, New York.

Hersey, G.L., 2009, Falling in love with statues: Artificial humans from pygmalion to the present, University of Chicago Press, Chicago, IL.

Hertzberg, H.W., 1974, I \& 2 Samuel: Old Testament Library, 3rd Imp., SCM Press, London.

Husbands, M. \& Treier, D.J. (eds.), 2005, The community of the Word: Toward an evangelical ecclesiology, InterVarsity Press, Downers Grove, IL.

Ito, H., 2015, 'The story of Jesus and the blind man: A speech act reading of John 9', Acta Theologica 2015(Supplementum 21), 1-524. https://doi.org/10.4314/actat. v21i1.1S

Joubert, S., 2017, 'Embracing obscurity: The enigmatic walk of the Son of God in Mark', In die Skriflig 51(3), a2100. https://doi.org/10.4102/ids.v51i3.2100

Louw, D.J., 2016, 'Preaching as art (imaging the unseen) and art as homiletics (verbalising the unseen): Towards the aesthetics of iconic thinking and poetic communication in homiletics', HTS Teologiese Studies/Theological Studies 72(2), a3826. https://doi.org/10.4102/hts.v72i2.3826

Mancini, W., 2008, Church unique: How missional leaders cast vision, capture culture, and create movement, Jossey-Bass, A Wiley Imprint, Hoboken, NJ.

Mashau, T.D. \& Mangoedi, L., 2015, 'Faith communities, social exclusion, homelessness and disability: Transforming the margins in the City of Tshwane', HTS Teologiese Studies/Theological Studies 71(3), Art. \#3088, 9 pages. https://doi.org/10.4102/ hts.v71i3.3088

McGrath, A.E., 1997, The genesis of doctrine: A study in the foundation of doctrina criticism, W.B. Eerdmans Publishing Company, Grand Rapids, MI.

Mickelsen, A.B., 1977, Interpreting the Bible, W.B. Eerdmans Publishing Company, Grand Rapids, MI.

Moltmann, J., 1993, The crucified God: The Cross of Christ as the foundation and criticism of Christian Theology, Fortress Press, Minneapolis, MN.

Nasrallah, L.S., 2011, Christian responses to Roman art and architecture: The secondcentury church amid the spaces of empire, Cambridge University Press, New York.

Nicolaides, A., 2014, 'The Seventh Ecumenical Council and the Veneration of Icons in Orthodoxy', Acta Theologica 34(2), 77-93. https://doi.org/10.4314/actat.v34i2.5

Onyewuenyi, I.C., 2000, 'Traditional African aesthetics: A philosophical perspective', in P.H. Coetzee \& A.P.J. Roux (eds.), Philosophy from Africa: A text with readings, pp. 396-400, Oxford University Press, Oxford.

Parsely, R., 2007, Culturally incorrect: How clashing worldviews affect our future, Thomas Nelson Publishers, Nashville, TN.

Peters, T., 2000, God - The world's future: Systematic theology for a new era, 2nd edn. Fortress Press, Minneapolis, MN.

Pretorius, H. \& Jafta, L., 1997, 'A branch springs out: African initiated churches', in R. Elphick \& R. Davenport (eds.), Christianity in South Africa: A political, social \& cultural history, pp. 211-226, David Philip Publishers/Oxford, James Currey Publishers, Claremont, CA.

Punt, J., 2016, 'Paul, military imager and social disadvantage', Acta Theologica 2016(Suppl 23), 201-224. https://doi.org/10.4314/actat.v23i1S.10

Rhodes, S.A., 1998, Where the nations meet: The church in a multicultural world, InterVarsity Press, Downers Grove, IL.

Ridderbos, H., 1975, Paul: An outline of his theology, transl. J.R. De Witt, W.B. Eerdmans Publishing Company, Grand Rapids, MI.

Senokoane, T., 2015, 'A white mist in the black Unisa', Scriptura 114(1), 1-11, viewed 18 April 2017, from http://scriptura.journals.ac.za

Sinding-Larsen, S., 1984, Iconography and ritual: A study of analytical perspectives, Universitetsforlaget AS, Oslo.

Storey, P., 2012, 'Banning the flag from our churches: Learning from the church-state struggle in South Africa', in W. Bentley \& D.A. Forster (eds.), Between capital and cathedral: Essays on church-state relationships, pp. 1-20, UNISA, Pretoria.

Stott, J., 2009, The Cross of Christ, 20th anniversary edn., Inter-Varsity Press, Nottingham.

Tillich, P., 1970, Love, power, and justice: Ontological analyses and ethical application, Oxford University Press, New York.

Van der Kooi, C. \& Van den Brink, G., 2017, Christian dogmatics: An introduction, W.B Eerdmans Publishing Company, Grand Rapids, MI.

VanGemeren, W.A., 1990, Interpreting the prophetic word: An introduction to the prophetic literature of the old testament, Zondervan Publishing House, Grand prophetic liter
Rapids, MI.

Villa-Vicencio, C. \& Grassow, P., 2009, Christianity and the Colonisation of South Africa, 1487-1883: A Documentary History, vol 1, UNISA Press, Pretoria.

Vlachos, G., 2017, 'A Theological approach to understanding the Byzantine icon of the Nativity of Jesus Christ', Pharos Journal of Theology 98, 1-14.

Ward, K., 1999, God, faith, and the new millennium: Christian belief in an age of science, Oneworld Publications, Oxford.

Wilkinson, J.R., 2000, 'Using and abusing African art', in P.H. Coetzee \& A.P.J. Roux (eds.), Philosophy from Africa: A text with readings, pp. 383-395, Oxford University Press, Oxford. 